\title{
A Note on the 18th Party Congress of the CCP: Personnel Changes and Factional Alliances
}

\author{
KJELD ERIK BRØDSGAARD
}

\begin{abstract}
The 18th Party Congress was more dramatic than anticipated due to the completely non-transparent process of selecting new leaders as well as a number of scandals involving leaders competing for the top posts. This contrasts with 2002 when Hu Jintao became secretary general in a comprehensive change of power that took place without much drama.

Keywords: Chinese Communist Party, Party Congress, Chinese politics, political transition, corruption
\end{abstract}

\section{Corruption and Scandals}

In February 2012, Bo Xilai, one of the contenders for membership of the new Standing Committee, ran into big trouble when his trusted police chief, Wang Lijun, fled to the US Consulate in Chengdu and revealed that Bo Xilai's wife Gu Kailai was involved in the murder of Neil Heywood, a British businessman. One month later, Bo Xilai was suspended from the Politburo and the Central Committee (CC) of the Chinese Communist Party (CCP) and an investigation into his involvement in corruption and neglect of official duties was instigated by the Party's Central Disciplinary Inspection Committee. This came as a shock to his supporters and it was rumoured that there were clashes between the police loyal to Premier Wen Jiabao, who formulated the first official criticism of Bo Xilai, and armed police directed by the conservative security czar Zhou Yongkang, widely recognized to have supported Bo Xilai's Chongqing experiments. ${ }^{1}$

In March, another serious incident took place involving Ling Jihua, a top contender for a Politburo seat. Ling Jihua's son was killed in a car accident driving a black Ferrari (Schultz 2012). With him were two half-naked women of Tibetan origin. They were both seriously injured. In the beginning, Ling Jihua succeeded in covering up the incident, but 
in June, the Hong Kong press began to unravel the story. And in July, Ling Jihua was forced to step down as director of the CC general office to take up the post as director of the general office of the CCP United Front Department instead (Brødsgaard 2012a). According to the South China Morning Post, ${ }^{2}$ the head of the large Chinese oil company CNPC, Jiang Jiemin, on behalf of Ling Jihua, had paid millions of yuan to families of the injured women. Whether the story is true or not, it highlights the close and sometimes nepotistic relationship between top officials and the state-owned enterprises in China.

As if this were not enough, the New York Times in October 2012 published a long article detailing how the family of Wen Jiabao controlled a business empire worth US\$2.7 billion (Barboza 2012). A great deal of the money was acquired by speculating on the listing of the insurance company Ping An Insurance. Wen Jiabao's mother controlled stocks worth US\$120 million. The story appeared to question Wen Jiabao's image as a clean and uncorrupted official.

\section{New Standing Committee}

Until the very end of the congress there was much speculation concerning the composition of the new top leadership (see also Li 2012). Would there be nine or seven members and would reform-oriented Party leaders such as head of the Central Organization Department, Li Yuanchao, and Party secretary in Guangdong Province, Wang Yang, make it? Finally, the day after the conclusion of the congress, when the new Central Committee met, it was revealed that the new Standing Committee would consist of Vice President Xi Jinping, Executive Vice Premier Li Keqiang, Chongqing Party Secretary Zhang Dejiang, Shanghai Party Secretary Yu Zhengsheng, Head of the Central Propaganda Department Liu Yunshan,Vice Premier Wang Qishan and Tianjin Party Secretary Zhang Gaoli. The new leadership team is characterized by provincial experience (all except Liu Yunshan have worked as provincial Party secretaries) and by seniority (all the two-term Politburo members under the age of 68 have been promoted). It is also a team that lacks reform credentials and clear visions for change.

During the 1990s and 2000s, the Party's cadre corps became younger. This trend has been reversed at the top of the power pyramid. Yu Zhengsheng is, at 67, the oldest member of the Standing Committee, closely followed by Zhang Dejiang and Zhang Gaoli at 66, Liu Yunshan at 65 and Wang Qishan at 64. Xi Jinping and Li Keqiang are the youngest, at 
TABLE 1: Newly elected members of the Standing Committee of the CCP Politburo (November 15, 2012)

\begin{tabular}{|l|l|c|}
\hline Name & Confirmed and designated positions & Age \\
\hline Xi Jinping & $\begin{array}{l}\text { CCP Secretary General, Chairman of } \\
\text { CMC, President }\end{array}$ & 59 \\
\hline Li Keqiang & Premier of State Council & 57 \\
\hline Zhang Dejiang & $\begin{array}{l}\text { Chairman of the National People's } \\
\text { Congress }\end{array}$ & 66 \\
\hline Yu Zhengsheng & $\begin{array}{l}\text { Chairman of the Chinese People's } \\
\text { Political Consultative Conference }\end{array}$ \\
\hline Liu Yunshan & $\begin{array}{l}\text { Executive Secretary of CCP Secretariat, } \\
\text { Vice President }\end{array}$ \\
\hline Wang Qishan & $\begin{array}{l}\text { Secretary of the Central Disciplinary } \\
\text { Inspection Commission }\end{array}$ & 64 \\
\hline Zhang Gaoli & $\begin{array}{l}\text { Executive Vice Premier of State } \\
\text { Council }\end{array}$ \\
\hline
\end{tabular}

Source: Author's database.

59 and 57 and the only members that are young enough to be re-elected at the next Party congress in 2017. The average age of the new Standing Committee is 63.4, compared to 62 for the Standing Committee elected at the 16th Party Congress in 2002, when Hu Jintao and Wen Jiabao took over. The average age of the members of the new Politburo is 61, compared to 60 for the Politburo elected in 2002. Members of the new Central Committee are also on average older than the members of the Central Committee elected at the 16th Party Congress.

The new general secretary, Xi Jinping, has worked his way up the Party hierarchy in the provinces and has been governor of Fujian province and Party secretary in both Zhejiang and Shanghai, but he has never held any central government positions. His rise to power shows the importance of provincial experience and connections in Chinese politics. In Zhejiang he was known to be supportive of market-friendly policies and foreign investment, but whether this would indicate a dedicated reformer is unclear. His father, Xi Zhongxun, supported Deng Xiaoping in initiating reform in the late 1970s and early 1980s and was actually the main figure behind the establishment of special economic zones in Guangdong province, where he served as Party secretary during the early reform period. However, should Xi Jinping harbour any ideas of initiating new reforms he will be constrained by the presence of conservative colleagues in the Standing Committee. It is rumoured that $\mathrm{Xi}$ Jinping is not $\mathrm{Hu}$ Jintao's top choice for general secretary. However, 
when a straw poll was held in 2007 among 300 top officials for Politburo membership, Xi received more votes than $\mathrm{Hu}$ Jintao's preferred choice, $\mathrm{Li}$ Keqiang, and was put in place as the new leader, with Li Keqiang as number two. In terms of education, $\mathrm{Xi}$ has a master's degree in chemical engineering and a PhD in law from Qinghua University. As the son of a former Politburo member and vice premier, he belongs to the faction of princelings. He is also considered to be close to Jiang Zemin's Shanghai Gang. Xi Jinping gave a good impression on November 15, when he presented the new leadership team. He made a speech without the usual tired official slogans and rhetoric.

When the new leadership team was presented, Li Keqiang appeared as number two. Like Xi Jinping, he has solid provincial experience. He has been Party secretary in both Henan and Heilongjiang provinces. But he also has another set of experiences working in the Communist Youth League (CCYL) where he eventually became first secretary of the Secretariat of the CCYL Central Committee, which is a ministerial-level position. He was long considered to be the core of the fifth generation, which was to take over from the fourth generation at the 18th Party Congress. However, in the end, senior leaders put him behind Xi Jinping as the preferred choice. He remains Hu Jintao's only clear ally on the new Standing Committee. In terms of education, he has a PhD in economics from Peking University. At 57, he is the youngest among the new leaders and will only be 67 when he retires in 2022.

In the new Standing Committee, Zhang Dejiang will be ranked number three as Chairman of the National People's Congress (NPC). This means that the premiership again will be considered the second most important position in China as was the case before Li Peng became Chairman of the NPC in 1997. Zhang Dejiang has been Party secretary in Jilin, Zhejiang and Guangdong and a member of the Politburo since 2002. In 2007 he was moved to Beijing to become executive vice premier in the Chinese State Council and member of the Standing Committee. He is the only one of the new leaders who has studied abroad. However, he studied economics at the Kim Il Sung University in Pyongyang, North Korea, and was never exposed to a Western-type education. He is a protégé of Jiang Zemin and is known to have good personal relations in the heavy-industrial sectors of the Chinese economy. As his father was a major general in the People's Liberation Army (PLA), he is also a princeling like Xi Jinping. In March 2012, Zhang Dejiang was sent to Chongqing to clear up the mess after the Bo Xilai affair. 
As chairman of the Political Consultative Conference, Yu Zhengsheng will be number four in the new Standing Committee. Educated as an engineer, he has held positions in Shandong province as well as in several ministries. He was minister of construction before he became Party secretary in Hubei in 2001. He succeeded Xi Jinping as Party secretary in Shanghai when Xi was transferred to Beijing in 2007 to become a member of the Standing Committee. Yu is the son of Huang Jing, the ex-husband of Jiang Qing, who later married Mao Zedong and served as Mayor of Tianjin in the early 1950s. He belongs to the princeling faction and is considered to be a protégé of both Deng Xiaoping and Jiang Zemin. Given that he is only slightly younger than $\mathrm{Hu}$ Jintao and Wen Jiabao, he can hardly be labelled a member of the new fifth generation of leaders.

Liu Yunshan is ranked number five in the new Standing Committee and is slated to become first secretary of the Secretariat of the Politburo. He is also expected to become vice president when the NPC meets for its annual session in the spring of 2013. He has long been underestimated among China analysts in the West, and not considered a strong candidate for promotion to the Standing Committee due to a relatively poor educational background. He has an undergraduate degree in journalism and took graduate courses (part time) at the Central Party School. He worked in the propaganda field in Inner Mongolia in the 1970s and 1980s and as deputy Party secretary of the CCYL Committee in Inner Mongolia. He was appointed deputy head of the Propaganda Department in 1993 and took over the leadership of the department in 2002 when Ding Guangen retired. The same year he became a member of the Politburo. As he has worked in the youth league, he is considered an ally of $\mathrm{Hu}$ Jintao. However, he also has family ties to the princeling faction.

Wang Qishan is ranked number six in the new leadership line-up. His portfolio will be to head the Party's Central Disciplinary Inspection Commission (CDIC), which is the Party's primary watchdog against corruption among leading Party members. He is a historian by training, but has worked in the banking sector for more than a decade and was governor of the China Construction Bank in the mid-1990s. Subsequently, he served as vice-governor of Guangdong, Party secretary of Hainan and mayor of Beijing before he was appointed vice premier in 2007 with responsibility for economic policies. He is a good example of the revolving doors between Party, state and big business in China. As a son-in-law of Yao Yilin, a former Standing Committee member and vice premier, he belongs to the princeling group. He is considered to be a protégé of former premier Zhu Rongji. He is known as a tough 
and able politician and his appointment to head the disciplinary commission is an indication of the serious attention that will be given to combating corruption.

Zhang Gaoli is ranked seven among the Standing Committee members. He is expected to become vice premier in charge of economic work. He is trained as an economic statistician and has pursued mid-career studies at the Central Party School. He spent 15 years holding various positions in the oil industry before becoming vice governor of Guangdong province. He has also served as Party secretary of Shenzhen, Shandong and Tianjin. He is considered a protégé of Jiang Zemin and former vice president and Standing Committee member Zeng Qinghong.

Apparently the Standing Committee was reduced to seven members in order to create a more operational leadership body. The former Standing Committee was often unable to make quick decisions due to its large size and the many often conflicting interests represented by the members. However, another possible reason for cutting the number of seats on the Standing Committee might be that it would be easier to bypass Wang Yang and Li Yuanchao.

\section{The New Politburo}

At the first plenary session of the 18th Central Committee, 14 new members were elected to replace those members of the Politburo that had to retire due to age requirements. The rule is that it is possible to be elected or re-elected at the age of 67 . For those aged 68 and above, retirement is mandatory. The new members include several regional leaders, such as the Party secretaries of Sichuan, Shaanxi, Fujian, Jilin, Xinjiang, and Beijing, and the mayor of Shanghai. Among the regional leaders, it is noteworthy that two so-called sixth generation leaders made it to the Politburo. These are the 49-year-old Party secretary of Jilin, Sun Zhengcai, and the 49-year-old Party secretary of Inner Mongolia, Hu Chunhua. They are both considered strong candidates for taking over top leadership positions in 2022, when Xi Jinping and Li Keqiang step down. $\mathrm{Hu}$ Chunhua, also called 'little $\mathrm{Hu}^{\prime}$ ', is widely assumed to be $\mathrm{Hu}$ Jintao's top candidate to become secretary general. He served as first secretary of the CYLC Central Committee before becoming governor of Hebei province in 2008 and Party secretary of Inner Mongolia Autonomous Region in 2009.

Other new members include Ma Kai, the former head of the National Development Reform Commission (NDRC) and current secretary gen- 
eral of the state council; Li Jianguo, the secretary general of the NPC; Li Zhanshu, the director of the CCP Central Committee's General Office; Wang Huning, the head of the CC Policy Research Office; PLA general Fan Changlong, vice-chairman of the CCP Military Commission; and the air force general Xu Qiliang, vice-chairman of the CCP Military Commission. Moreover, the Minister of Public Security, Meng Jianzhu, has been promoted to the Politburo and will take over the portfolio of the Political and Legal Affairs Commission, which no longer will be handled by a member of the Standing Committee. Finally, with Sun Zhengcai's promotion to the Politburo, female representation has been doubled, as the only female Politburo member previously, Liu Yandong, has been re-elected.

It is noteworthy that Ling Jihua was not elected to the Politburo. Until the spring of 2012, he served as Hu Jintao's chief of staff in his capacity as director of the Central Committee's General Office. He was predicted to enter the Politburo and some analysts even believed he might make it to the Standing Committee. However, his son's car crash in March 2012 and subsequent attempts to cover up the incident seem to have ended a promising career.

It is also noteworthy that the new Politburo is more balanced in terms of factional affiliation than the Standing Committee. Among the Standing Committee members, four can be considered princelings and part of Jiang Zemin's camp. In addition, although not a princeling, Zhang Gaoli is also a protégé of the former Party leader. However, in the wider Politburo there is a factional balance between Jiang's camp and Hu's camp. Twelve members can be considered to belong to Jiang's faction, whereas eleven belong to Hu's faction. Two members, Liu Yunshan and Li Zhanshu, have unclear affiliations. However, Liu Yunshan, although he has princeling connections through his family, is most probably leaning towards $\mathrm{Hu}$ Jintao and the CYCL faction and is listed under Hu's faction in the table below.

\section{Central Committee}

The 18th Party Congress elected a new Central Committee consisting of 205 full members and 171 alternates. There are 240 new members (64 per cent of total membership). The average age of the new CC is 56 years, one year older than the 16th CC. ${ }^{3}$ Predictably, everyone born before 1945 has been retired. 
TABLE 2: The Composition of the Politburo of the 18th Central Committee of the CCP (November 15, 2012)

\begin{tabular}{|c|c|c|c|c|}
\hline Name & Age & Position & $\begin{array}{l}\text { Jiang's } \\
\text { Faction }\end{array}$ & $\begin{array}{c}\text { Hu's } \\
\text { Faction }\end{array}$ \\
\hline Xi Jinping & 59 & $\begin{array}{l}\text { Secretary General, President, } \\
\text { CMC Chair }\end{array}$ & $x$ & \\
\hline Li Keqiang & 57 & Premier of State Council & & $x$ \\
\hline Zheng Dejiang & 66 & Chairman of NPC & $x$ & \\
\hline Yu Zhengsheng & 67 & Chairman of CPPCC & $x$ & \\
\hline Liu Yunshan & 65 & $\begin{array}{l}\text { Executive Secretary of Secretariat, } \\
\text { Vice President }\end{array}$ & & $\mathrm{x}$ \\
\hline Wang Qishan & 64 & Secretary of CCDI & $x$ & \\
\hline Zhang Gaoli & 66 & $\begin{array}{l}\text { Executive Vice Premier of State } \\
\text { Council }\end{array}$ & $x$ & \\
\hline Ma Kai & 66 & Secretary General of State Council & $x$ & \\
\hline Wang Huning & 57 & Head of CC Policy Research Office & $x$ & \\
\hline Liu Yandong (f) & 67 & State Councilor & & $x$ \\
\hline Liu Qibao & 59 & Sichuan Party Secretary & & $x$ \\
\hline Xu Qiliang & 62 & Vice Chairman of the CMC & $x$ & \\
\hline Sun Chunlan (f) & 62 & Fujian Party Secretary & & $x$ \\
\hline Sun Zhengcai & 49 & Jilin Party Secretary & $x$ & \\
\hline Li Jianguo & 66 & NPC Secretary General & & $x$ \\
\hline Li Yuanchao & 62 & $\begin{array}{l}\text { Former head of CCP Central } \\
\text { Organizational Department }\end{array}$ & & $x$ \\
\hline Wang Yang & 57 & Guangdong Party Secretary & & $x$ \\
\hline Zhang Chunxian & 59 & Xinjiang Party Secretary & $x$ & \\
\hline Fan Changlong & 65 & Vice Chairman of the CMC & & $x$ \\
\hline Meng Jianzhu & 65 & Minister of Public Security & $x$ & \\
\hline Zhao Leji & 55 & Shaanxi Party Secretary & & $x$ \\
\hline Hu Chunhua & 49 & Inner Mongolia Party Secretary & & $x$ \\
\hline Li Zhanshu & 62 & Director of CCP General Office & $?$ & $?$ \\
\hline Guo Jinlong & 65 & Beijing Party Secretary & & \\
\hline Han Zheng & 58 & Shanghai Mayor & $x$ & \\
\hline
\end{tabular}

Source: Author's database

Note: The first seven listed above are Politburo Standing Committee members.

Newly elected members include Guizhou's deputy Party secretary, Chen Miner (b. 1960); chairman of Xinjiang Autonomous Region, Nur Bekri (b. 1961); Fujian governor and former head of Sinopec, Su Shulin (b. 1962); and first secretary of CYCL, Lu Hao (b. 1967). At 45, Lu Hao is the youngest $\mathrm{CC}$ member. There are 39 national minorities and 33 women members in the new CC.

A number of leaders of the large state-owned enterprises were elected to full membership of the CC, including Ma Xingrui of China Aerospace Science and Technology Corporation and Xu Dazhe of China Aerospace 
Science and Industry Corporation. Zhang Guoqing of China North Industries Group; Lin Zuoming of China Aviation Industry Corporation; and Jiang Jiemin of China National Petroleum Corporation (CNPC) were moved from alternate to full membership. Wang Xiaochu of China Telecom Corporation kept his alternate membership. Ren Hongbin of China National Machinery Industry Corporation and Zhang Xiwu of Shenhua Group Corporation were elected new alternate members. ${ }^{4}$ Surprisingly, the head of State Grid, Liu Zhenya, lost his alternate membership of the CC. In the 17th Central Committee there were only two full members of the CC among the business leaders: Kang Rixin, general manager of China National Nuclear Corporation and Zhang Qingwei, president of China Commercial Aircraft Corporation. Due to corruption charges, Kang Rixin was expelled from the CC in October 2010 and in 2011 Zhang Qingwei was transferred to Hebei to take up the post of governor and deputy Party secretary.

Similar to previous Party congresses, a method of multi-candidate election for the CC known as 'more candidates than seats' (cha'e xuanju) was utilized. For full membership of the CC there were 224 candidates for the 205 seats and for alternate membership 171 leaders were elected out of 190 candidates. This means that 9.3 percent of candidates for full membership were eliminated and 11.1 percent for alternate membership. Unexpectedly, among the eliminated were Minister of Commerce Chen Deming (age 63) and Minister of Supervision Ma Wen (age 64). Minister of Finance Xi Xuren (65), Minister of NDRC Zhang Ping (66) and Central Bank Governor Zhou Xiaochuan (64) were also eliminated, even though they are of eligible age.

Quoting Mingiing News, Boxun.com has reported the final tally for the voting of the Party Congress. ${ }^{5}$ Of the ten candidates for the Standing Committee, $\mathrm{Xi}$ Jinping received the most votes (2,306), followed by Li Keqiang, Zhang Dejiang and Zhang Gaoli, who each received 2,305 votes. Liu Yandong got 2,301 votes, and Wang Yang and Yu Zhengsheng 2,300. Wang Qishan received 2,299, Liu Yunshan 2,294 and Li Yuanchao 2,287 . This means that even though Wang Yang received more votes than Wang Qishan and Liu Yunshan, the Party leadership decided to bypass him when they put together the final leadership team. Apparently he is too liberal-minded for the current Chinese leadership. It may also have played a role that Wang Yang, although he is at the other pole of the political spectrum within the Party, similar to Bo Xilai has popular support. The Party is still extremely careful to promote leaders according to inner-Party norms and rules rather than popular sentiments. 
TABLE 3: Number of votes for contenders to the Politburo Standing Committee of the 18th Central Committee

\begin{tabular}{|l|l|c|}
\hline Name & Position & Number of Votes \\
\hline Xi Jinping & Standing Committee & 2,306 \\
\hline Li Keqiang & Standing Committee & 2,305 \\
\hline Zhang Dejiang & Standing Committee & 2,305 \\
\hline Zhang Gaoli & Standing Committee & 2,305 \\
\hline Liu Yandong & Politburo & 2,301 \\
\hline Wang Yang & Politburo & 2,300 \\
\hline Yu Zhengsheng & Standing Committee & 2,300 \\
\hline Wang Qishan & Standing Committee & 2,299 \\
\hline Liu Yunshan & Standing Committee & 2,294 \\
\hline Li Yuanchao & Politburo & 2,287 \\
\hline
\end{tabular}

Following the Party Congress and the conclusion of the First Session Plenary of the 18th Central Committee, a number of important leadership appointments have been announced. They include the appointment of Shaanxi Party Secretary Zhao Leji to head the Central Organization Department and the appointment of Sichuan Party Secretary Liu Qibao to head the Propaganda Department. In Sichuan he will be succeeded by Wang Dongming, the director of the State Commission for Public Sector Reform. Reshuffling among provincial Party secretaries has also been announced. Thus, Sun Zhengcai will move from Jilin to Chongqing, Sun Chunlan will move from Fujian to Tianjin, and Han Zheng will be promoted to Party secretary in Shanghai (Xinhua 2012a). More appointments will follow in the coming weeks.

\section{Central Military Commission}

When Jiang Zemin stepped down as secretary general of the CCP in 2002 he continued two more years as head of the Party's Central Military Commission $(\mathrm{CMC})$ thereby maintaining significant power. This time, $\mathrm{Hu}$ Jintao decided to step down from all his positions, making it possible to carry through a complete power transfer. At its First Plenary Session, the 18th $\mathrm{CC}$ elected eight new members to the CMC. Actually, the two new vice chairmen, Air Force General Xu Qiliang and PLA General Fan Changlong were appointed to the $\mathrm{CMC}$ already before the commencement of the Party Congress. In addition to the two new vice chairmen and $\mathrm{Xi}$ Jinping, the new members include five generals: Zhang Youxia, director of the General Armament Department, Fang Fenghui, director of the General Staff De- 
partment, Zhang Yang, director of the General Political Department, Zhao Keshi, director of the General Logistics Department and Wei Fenghe, commander of the Second Artillery Corps. The commander of the PLA air force, Ma Xiaotian, was also appointed as a member. General Chang Wanquan, minister of National Defense, and Admiral Wu Shangli, commander of the PLA navy, continued their membership (Xinhua 2012b).

$\mathrm{Xi}$ Jinping is the only civilian. However, unlike Hu Jintao, he does have military experience and connections as he has worked as secretary for former Minister of Defense Geng Biao. In the previous CMC there were two civilians. The current CMC will most likely continue to have only one civilian until the 19th Party Congress in 2017, when Xi Jinping's successor among the emerging sixth generation may be appointed.

\section{New Fifth Generation}

The current leadership change was supposed to hand over the reins of power from the fourth generation to the fifth generation of Chinese leaders. The concept of a generation with one or two leaders as the core was first introduced by Deng Xiaoping in 1989. It has been repeated since then on several occasions, the latest in Hun Jintao's report to the 18th Party Congress. Mao's cohort ruled China from 1949 to 1976. Deng and his cohort, who ruled between 1978 and 1989, was named the second generation. Jiang Zemin was the core of the third generation (1989-2002) and $\mathrm{Hu}$ Jintao is the fourth (2002-2012). Since 2002, each generation is supposed to govern China for 10 years, which is the maximum tenure for state leaders. Therefore, the fifth generation with Xi Jinping as the core will rule China between 2012 and 2022.

Members of the outgoing Standing Committee were between 72 and 68 years old. It seems a bit peculiar to claim that the new members, who are between 64 and 67, represent a new generation of leaders. $\mathrm{Yu}$ Zhengsheng, Zhang Dejiang and Zhang Gaoli are more fourth generation than new fifth generation leaders. In this sense, the present transfer of power does not represent renewal. There is also no basis for expecting new economic and political reform on a major scale. Even if $\mathrm{Xi}$ Jinping should harbour wishes to accelerate reform, it remains to be seen whether he will be able to overcome resistance from his older and more conservative colleagues.

Whereas the new leaders do not represent major change in terms of age, their educational background is different from the retired members of the Standing Committee. Most of them were engineers, including both 
$\mathrm{Hu}$ Jintao and Wen Jiabao. Among the newly elected members, only one, $\mathrm{Yu} Z \mathrm{Zhengsheng,} \mathrm{is} \mathrm{an} \mathrm{engineer} \mathrm{by} \mathrm{education.} \mathrm{Two} \mathrm{are} \mathrm{economists}$ (Zhang Dejiang and Zhang Gaoli), one is a historian (Wang Qishan) and one a journalist (Liu Yunshan). The engineers no longer dominate the top leadership in China. Instead, economists are the most numerous among the various disciplines represented.

\section{Conclusion}

On the positive side, it is worth noting that for the second time since the death of Mao, the CCP has been able to carry through a political transition in a peaceful and orderly fashion in conformity with agreed rules and norms. This appears to show that the institutionalization of Chinese politics is continuing in a routine and stable manner. However, the age requirements have been stretched to the limit by appointing leaders who are very close to retirement age. Moreover, the many corruption cases show that behind the surface, politics is increasingly influenced by corruption. It is also increasingly possible to move ahead in the power system by engaging in bribery. As former Vice President Zeng Qinghong pointed out in a major article in 2004 in the People's Daily, whether or not the Party will be able to avoid corruption and strengthen its governing capacity will decide whether the present regime will continue to uphold its legitimacy or whether it will suffer the same fate as the Soviet Union and the East European puppet regimes in the late 1980s and early 1990s. ${ }^{6}$ The new leadership does well in remembering this warning.

Kjeld Erik Brødsgaard is Professor and Director at the Asia Research Centre, Copenhagen Business School.

\section{NOTES}

1 http://bbs.aboluowang.com/viewthread.php?tid=63961.

2 South China Morning Post, 14 November 2012. Available from http:/ / www.scmp. com/news/china/article/1081916/oil-chief-quizzed-over-bid-cover-death-huaides-son-ferrari-crash (accessed 30 November 2012).

3 For leadership appointments at the 16th Congress in 2002, see Brødsgaard (2002).

4 For the business group representation of the 16th and 17th Central Committees, see Brødsgaard (2012b).

5 http://www.boxun.com/news/gb/china/2012/11/201211191301.shtml\#. ULqEdWf0QeU.

6 For Chinese leaders' view on the lessons to be learnt from the collapse of the Soviet Union, see Shambaugh (2008). 


\section{REFERENCES}

Barboza, David. 2012. 'For Wen's family, hidden billions'. International Herald Tribune, October 27-28.

Brødsgaard, Kjeld Erik. 2012a. 'Murder, Sex and Corruption: Will China Continue to Hold Together?' Paper presented at the 10th EastAsiaNet Research Workshop, Universitat Autonoma de Barcelona, Barcelona, 25-26 October.

Brødsgaard, Kjeld Erik. 2012b. 'Politics and Business Group Formation in China: The Party in Control'. The China Quarterly 212(September): 624-648.

Brødsgaard, Kjeld Erik. 2002. 'The 16th Party Congress in China: A Note on Personnel Changes'. The Copenhagen Journal of Asian Studies 16: 138-149.

Follath, Erich, and Wieland Wagner. 2012. 'Ein mörderischer Machtkampf'. Der Spiegel 42: 89-98.

Li, Cheng. 2012. 'Opportunity Lost? Inside China's Leadership Transition'. Foreign Policy, November 25.

Shambaugh, David. 2008. China's Communist Party: Atrophy and Adaptation. Washington DC: Woodrow Wilson Center Press.

Xinhua. 2012a. 'CCP Officials' Appointments and Removals (Nov. 19-21)'. Available from http:/ / big5.xinhuanet.com/gate/big5/news.xinhuanet.com/english/photo/2012-11/22/c_131991725.htm (accessed 23 November 2012).

Xinhua. 2012b. 'List of Chairman, Vice Chairmen and Members of the CPC Central Military Commission'. Available from http://news.xinhuanet.com/english/special/ 18cpcnc/2012-11/15/c_131976516.htm (accessed 23 November 2012).

Schultz, Sandra. 2012. 'Ferrari-Unfall erschüttert Chinas Elite'. Available from http:/ / www.spiegel.de/politik/ausland/ling-jihua-wird-nach-unfall-mit-ferrari-von-chinas-kp-strafversetzt-a-853833.html (accessed 22 November 2012). 